\title{
Soberania e Escravidão
}

\author{
Rodrigo Fautinoni Bonciani ${ }^{1}$
}

\begin{abstract}
Resumo: O objetivo deste artigo é analisar a relação entre escravidão e soberania na história da América. O conceito de dominium, entre os séculos XVI e XVII, possuía um significado ambivalente, entre as noções de propriedade privada e de poder político, que definiu o paradoxo das relações entre a Coroa e os agentes coloniais mediadas pela tutela e escravidão dos indígenas e africanos. Quais foram os limites definidos pelo dominium senhorial e privado para a emergência da soberania? Analisaremos essa questão em quatro momentos da história americana: na política ultramarina Habsburgo para o Brasil e Angola, entre 1580 e 1640; na colonização britânica e francesa das Antilhas, na segunda metade do século XVII; na política reformista de meados do século XVIII; e nos processos de independência de Cuba, Brasil e EUA.

Palavras-chave: Soberania, escravidão, dominium.
\end{abstract}

\begin{abstract}
The aim of this paper is to analyze the relationship between slavery and sovereignty in American history. The concept of dominium, between the sixteenth and seventeenth centuries, had an ambivalent meaning, ranging from the concepts of private property and political power, which defined the paradox of the relationship between the Crown and the colonial agents mediated by tutelage and slavery of Indians and Africans. What were the limits set by seigniorial and private dominium to the emergence of sovereignty? We will review this issue at four moments of American history: the Habsburg policy overseas to Brazil and Angola, in the period of 1580 and 1640; the British and French colonization of the Antilles, in the second half of the seventeenth century; the reformist politics of the mid-eighteenth century; and the processes of independence of Cuba, Brazil and the United States.
\end{abstract}

Keywords: Sovereignty, slavery, dominium.

\section{Introdução}

O processo de formação dos Estados modernos entre os séculos XVI e XVIII revela um problema fundamental: a soberania política do Estado não pode se impor sobre as outras forças político-econômicas sem a apropriação e regulamentação das relações com a mão-de-obra. Sua intervenção se justifica porque a ordem social está ameaçada. No entanto, os limites da ação econômica e do controle social por parte do Estado exigem o estabelecimento de pactos com essas forças e a constituição de novas estruturas políticoadministrativas (instituições, leis e funcionários). Assim, a partir do controle das relações com a mão-de-obra, o Estado pretende subordinar essas forças ao seu poder. $\mathrm{O}$ favorecimento, por parte do mesmo, de alguma dessas forças político-econômicas pode gerar, a longo prazo, a emergência de um poder que ameaça a soberania do Estado. Nesse sentido, a tendência é ampliar o conjunto de forças político-econômicas e criar mecanismos de controle das mesmas: dividir para melhor governar. Ao mesmo tempo, as instituições e funcionários criados pelo Estado tendem a constituir interesses e práticas distintas das que emanam do centro de poder.

Esse é um dos problemas fundamentais do processo de formação dos Estados modernos e que perdura com a constituição dos Estados nacionais. Esse trabalho analisará

\footnotetext{
${ }^{1}$ Rodrigo Bonciani é doutorando em História Social no Departamento de História da FFLCH-USP.
} 
as relações entre a emergência da soberania do Estado e a escravidão no Brasil, Cuba, E.U.A. e nas Antilhas inglesas e francesas.

Para o período colonial ${ }^{2}$, momento onde se formula a hipótese deste trabalho, analisaremos as mudanças da política ultramarina durante a União Ibérica (1580-1640). A apropriação das conquistas portuguesas na América e na África permite aos reis Habsburgo constituir uma nova política colonial em relação aos indígenas, africanos e colonos. Os moradores resistem às interferências da Coroa nas relações com a mão-de-obra e se apropriam dos discursos de vassalagem para manter seu dominium ${ }^{3}$ sobre os indígenas e africanos. Nesse contexto, a definição do conceito de soberania por Jean Bodin ${ }^{4}$ está em harmonia com a política dos Felipes. Procuravam afirmar o poder do rei frente às forças senhoriais e os outros agentes político-econômicos presentes nas sociedades do Antigo Regime. Para isso era necessário que o dominium político, ou a soberania, estivesse por cima do dominium senhorial. As medidas da Coroa nas colônias implicaram na liberdade indígena, no favorecimento do tráfico de escravos africanos e na tentativa de controle do mesmo por parte da Coroa. A mão-de-obra desterritorializada aumentava a dependência dos colonos em relação à metrópole que também procurava interferir no governo dos indígenas e nas relações político-econômicas que envolviam a escravidão.

2 Como processo de colonização entende-se exatamente a capacidade da Coroa de exercer o poder sobre as terras (riquezas produzidas) e sobre seus habitantes (colonos e nativos). A expressão de Luiz Felipe de Alencastro "colonização dos colonos" nos parece especialmente feliz para determinar o principal desafio desse processo. ALENCASTRO, Luiz F. de. O Trato dos viventes: formação do Brasil no Atlântico Sul. São Paulo, Companhia das Letras, 2000, p. 21. Essa discussão também determina nossa opção pelos termos 'habitants', 'planters', 'vecinos', 'moradores', 'conquistadores', 'portugueses', e 'conquista', quando quisermos enfatizar o grau de autonomia que essas forças políticas possuíam em relação à Coroa. O termo 'colono' traz o sentido de conformação com os interesses metropolitanos e a 'colônia' é o espaço de realização dos mesmos. No entanto, por uma questão de repetição dos termos podemos utilizar 'colonos' e 'colônia'. Sobre a adequação do termo colono ver BOSI, Alfredo. Dialética da colonização. São Paulo, Companhia das Letras, 1994, pp. 11-19.

3 "Le terme dominium fait l'objet d'un long débat d'ordre conceptuel, jusqu'à la définition restrictive proposée par Hugo Grotius. Avant lui, la définition dominante et souvent reprise dans les traités juridiques, est celle élaborée par Domingo de Soto dans son traité De iustitia et iure, de 1556, qui comprend une double dimension: faculté et droit (facultas et ius) sur quelque chose, en vue d'une utilisation personnelle de l'objet de dominium, selon les formes autorisées par la loi. Dominium est donc distingué de possession, d'usage et usufruit, puisqu'il intègre également la dimension de l'aliénation. Une telle définition se prêtait néanmoins à des interprétations ambiguës (distinction entre dominium utile et dominium directum, par exemple), ce qui, dans le cas du dominium sur autrui (...). Dominium est un concpet intermédiaire entre la propriété (qui comprend le utendi, le fruendi, et l'abutendi, aujourd'hui résumés dans la notion de propriété privée) et la souveraineté (concept qui se précise aux XVIe siècle, sous la plume de Jean Bodin), et est à l'origine de la conception moderne de pouvoir politique, ou public". ZERON, Carlos Alberto. Tese de doutorado: La Compagnie de Jésus et l'institution de l'esclavage au Brésil : les justifications d'ordre historique, théologique et juridique, et leur intégration par une mémoire historique (XVI-XVII siècles). Ecole des Hautes Etudes en Sciences Sociales de Paris, 1998, p. 181. O dominium relacionado à propriedade será tratado nesse ensaio como dominium pessoal (quando fizer referência ao poder dos senhores sobre seus escravos) ou dominium patrimonial e dominium senhorial (para um sentido mais amplo do conceito). Dominium político e soberania serão utilizados como sinônimos.

4 BODIN, Jean. Les six livres de la République. Paris, 1576, ou, Darmstadt, Scientia Verlag Aalen, 1977 (facsimile de la deuxième édition, Paris, 1583). 
Com o desenvolvimento da indústria açucareira nas Antilhas, a partir da segunda metade do século XVII, franceses e ingleses passaram a lidar com o tênue equilíbrio das sociedades escravistas. Analisaremos essas experiências no segundo capítulo deste ensaio. Essas Coroas criaram modelos distintos na relação entre senhores e escravos. A Inglaterra evitou qualquer interferência no governo dos escravos, enfatizando o poder dos senhores sobre suas propriedades. Enquanto no caso francês, e com nítida influência da política felipina, houve uma forte interferência e tentativa de regulamentação das relações com a mão-de-obra. Faremos uma análise comparativa tendo como referência o Barbados Act de 1661 e o Code Noir de 1685. Se no primeiro capítulo apresentamos a hipótese de trabalho, neste segundo se revela uma contradição estrutural. A tentativa da Coroa francesa de interferir no dominium senhorial, e reafirmar seu dominium político sobre os habitantes e sobre as colônias, revela que grande parte do seu poder também está fundamentada no patrimonialismo. ${ }^{5}$

Estes conflitos terão nova configuração a partir das políticas reformistas de meados do século XVIII. Nas colônias portuguesas, a partir das reformas pombalinas, reafirma-se a estratégia de proibição da escravidão indígena e estabelecimento de companhias monopolistas que devem incrementar o fornecimento de escravos africanos. Na Inglaterra a tendência é deixar o governo dos escravos na mão dos planters. Já no caso de França e Espanha existe uma clara tentativa de interferência no governo dos escravos. Essas medidas foram um dos motivos de instabilidade nas Antilhas e, em Cuba, elas foram rejeitadas pela sacarocracia. Se as tentativas de interferência no governo dos indígenas e a subordinação dos chefes africanos, no início do século XVII, tiveram grande resistência dos agentes da colonização, no final do século XVIII as sociedades americanas já tinham consolidado sua particularidade histórica. A experiência de São Domingos foi exemplar dos perigos que podiam representar as tentativas de reforma colonial em momentos de crise da soberania. A exigência por maior participação política e o questionamento das formas de dominação eram como bolas de neve: partiam do topo da hierarquia social e engrossavam conforme desciam a montanha.

Conflagrada a crise do sistema colonial emergem as lutas de independência na América. Novamente a relação entre os Estados emergentes e o controle sobre a mão-deobra serão centrais na definição das rupturas e continuidades em relação ao período anterior. No caso dos E.U.A. o conflito entre a emergência da soberania do Estado e a escravidão foi territorializada e levou a Guerra de Secessão. Na América latina, os dois

5 Sobre o conceito de patrimonialismo ver FAORO, Raymundo. Os Donos do Poder: formação do patronato político brasileiro. São Paulo, Globo-Publifolha, 2000, 2 vols. 
países latino-americanos que preservaram características políticas do período anterior também mantiveram o sistema produtivo escravista: Cuba e Brasil. O primeiro continuou colônia e o segundo manteve a dinastia Bragança no poder.

Grande parte da historiografia que trata dos processos de independência na América teve como ponto de partida as reformas políticas de meados do século XVIII. ${ }^{6}$ Perdeu-se, portanto, a perspectiva de longa duração, fundamental para entender as continuidades e rupturas destes processos. Se perdermos de vista a relação intrínseca entre os processos de formação dos Estados modernos e a necessidade de apropriação e regulamentação das relações com a mão-de-obra, não reconheceremos as implicações políticas da escravidão e de sua abolição. A historiografia, até data muito recente ${ }^{7}$, tratou estes temas separadamente. O processo de abolição da escravidão se transformou num tema independente e perdeu-se a perspectiva política do tema. É fundamental recuperar a escravidão nesta perspectiva: desde a formação do sistema colonial até os processos de emancipação e formação dos países americanos.

\section{O governo do gentio e o comércio de escravos durante a União Ibérica}

O debate sobre o tema da escravidão, durante os processos de independência na América, variou em função da importância dos escravos no sistema produtivo de cada país. No período colonial os negros, indígenas e mestiços foram a mão-de-obra que permitiu o desenvolvimento do sistema colonial. O predomínio da mão-de-obra negra, indígena ou mestiça dependeu das características de cada região e sua forma de inserção na economia mundial. É importante observar as distintas modalidades de trabalho que coexistiam ao lado da escravidão e os mecanismos de alforria que revelam a complexidade das sociedades coloniais.

\footnotetext{
6 Um exemplo disto está presente nesse trecho de WEBER, David J.: "A principios del siglo la fatigada dinastía de los Austrias había cedido el paso al dinamismo de los Borbones". In: Bárbaros : Los españoles y sus salvajes en la era de la Ilustración. Barcelona, Crítica, 2007, p. 16.

$7 \mathrm{Na}$ historiografia sobre o Brasil devemos destacar o trabalho de SCHULTZ, Kirsten. "La independencia de Brasil, la ciudadanía y el problema de la esclavitud: A Assembléia Constituinte de 1823". In: RODRÍGUEZ O., Jaime (coord.). Revolución, independencia y las nuevas naciones de América. Madri, Fundación Mapfre Tavera, 2005, pp. 425-449. MARQUESE, Rafael de Bivar, trata essas questões para o Brasil, Cuba, E.U.A. e Antilhas in: Feitores do corpo, missionários da mente: Senhores, letrados e o controle dos escravos nas Américas, 1660-1860. São Paulo, Companhia das Letras, 2004. Sobre os debates na península Ibérica e na América hispânica ver: VILA VILAR, Enriqueta. "La esclavitud americana en la política española del siglo XIX”. Estudios Latinoamericanos, 6, II, 1980, pp. 385-403. O caso do Haiti é excepcional para essa perspectiva de análise porque é o único caso em que independência e abolição acontecem simultaneamente, destacamos os trabalhos de JAMES, C. L. R. Los jacobinos negros: Toussaint L'Ouverture y la Revolucion de Haiti. Madri, Turner; México, Fondo de Cultura Económica, 2003. FISCHER, Sibylle M. Modernity disavowed : Haiti and the cultures of slavery in the age of revolution. Durham, Londres, Duke University Press, 2004. FICK, Carolyn. The making of Haiti - The Saint Domingue Revolution from Below. Knoxville, The University of Tennessee Press, 1990.
} 
Outro papel cumprido pelos negros e indígenas no processo colonial foi o da ocupação e defesa do território. Inicialmente, a baixa densidade populacional européia, exigia a aliança com os povos indígenas para a ocupação e defesa da terra (das invasões estrangeiras e das tribos inimigas). Os escravos africanos também foram utilizados no sistema de defesa das colônias. Este é outro aspecto fundamental para entender os mecanismos de dominação colonial sobre os negros e os indígenas, assim como entre boçais e ladinos, ou entre mestiços e nativos; se criou um antagonismo jurídico e social entre eles. ${ }^{8}$

O que interessa destacar agora é que tanto os negros como os indígenas tiveram importância como mão-de-obra e, secundariamente, militar. Esta mesma situação se apresentará nos processos de independência. Mas o fator determinante será o grande peso destas populações no sistema produtivo.

O envolvimento do Estado com a questão indígena, com o tráfico de escravos e com os poderes econômico-políticos nos remetem à formação do sistema colonial. As metrópoles, portuguesa e espanhola, desde o século XVI fizeram esforços para regularizar e controlar as relações com a mão-de-obra fosse indígena ou africana. No caso da América espanhola essa política se evidencia a partir da elaboração das Leyes Nuevas de $1542^{9}$ (que pretendem extinguir os serviços pessoais indígenas) e com o envio de visitadores à América. O objetivo é passar de um sistema de dominium senhorial, exercido pelos encomenderos em

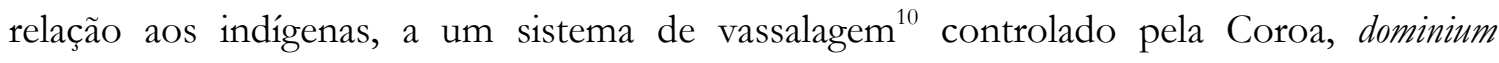
político. Um destes visitadores, assim expressa a vinculação entre a aplicabilidade das Leyes Nuevas e a escravidão africana:

"E si Vuestra Alteza fuere servido de mandar inviar algunos negros para este destrito, soy cierto que serian bien pagados e Vuestra Alteza les haria grande merced e seria cautela para que las leyes de Vuestra Alteza se guardasen mejor,

\footnotetext{
8 Para o caso espanhol ver LUCENA SALMORAL, Manuel. "Leyes para esclavos : El ordenamiento jurídico sobre la condición, tratamiento, defensa y represión de los esclavos en las colonias de la América español”. In: ANDRÉS-GALLEGO, José (dir. e coord.). Tres grandes cuestiones de la historia de Iberoamérica. Fundación Ignácio Larramendi, Fundación Mapfre Tavera. Madri, s.d. (CD-Rom). Na legislação portuguesa não fica tão evidente seus aspectos racistas, ver LARA, Silvia Hunold (org.). "Legislação sobre escravos africanos na América portuguesa". In: Ibidem. E para o caso inglês ver MORGAN, Edmund. American slavery, American freedom. The ordeal of colonial Virginia. Nova York, W. W. Norton, 1975, pp. 312-337. MORGAN, Philip. Slave counterpoint - black culture in the eighteenth century Chesapeake \& lowcountry. Chapel Hill, University of North Carolina Press, 1998, pp. 14 e 15. BERLIN, Ira. Many thousands gone the first two centuries of slavery in North America. Cambridge, Mass., Belknap Press, 1998, pp. 109-117. BLACBURN, Robin. The making of New World slavery - from the Baroque to the Modern, 1492-1800. Londres, Verso, 1997, pp. 256-258. JORDAN, Winthrop. White over black - American attitudes toward the negro, 1550-1812. Chapel Hill, University of North Carolina Press, 1968, pp. 71-82.

9 Biblioteca Virtual Miguel de Cervantes. Miscelánea de textos breves relativos a la época del emperador. Espanha, Madri. http://www.cervantesvirtual.com/historia/CarlosV/9 15.shtml. 9 de enero de 2007.

10 Em que o índio, livre, devia prestar serviços públicos e privados (assalariado), e pagar tributos, em troca de justiça, comércio e conhecimento da fé católica.
} 
porque estos pobladores padecen de grande necesidad de servicio, por quitársele tan de golpe y sin apercibillos los esclavos e servicio personal". ${ }^{11}$

No Brasil, as primeiras políticas neste sentido, podem ser observadas a partir da instituição do governo geral em 1549 e revelam a influência da política colonial espanhola em Portugal. ${ }^{12}$ A Coroa portuguesa atua em duas frentes: constitui um aparato políticoadministrativo (leis, instituições e funcionários) com intenção de subordinar os poderes locais e encontrará na Companhia de Jesus os aliados estratégicos capazes de intermediar as relações entre os moradores e os indígenas.

A política Habsburgo teve muita importância neste esforço de superar o dominium senhorial (exercido pelos amos sobre os indígenas e africanos) em nome da soberania régia. Com Felipe II, o sentido geral da política ultramarina favoreceu as distintas forças políticoeconômicas presentes nas colônias: dividir para melhor controlar.

No Brasil, por exemplo, acaba o monopólio jesuítico sobre a evangelização. O rei favorece a entrada de outras ordens religiosas. A Coroa aumenta as doações feitas a estas para afastá-las da produção colonial, exigindo sua dedicação às questões espirituais. Os governadores escolhidos neste período se opõem ao poder dos jesuítas sobre os indígenas. ${ }^{13}$ Elabora-se o primeiro projeto de um tribunal de justiça para o Brasil, em que o tema indígena tinha destaque. ${ }^{14}$ Estimula-se também a política expansionista para o Norte do país que interessava aos moradores que viam nestas expedições a possibilidade de aquisição de novas terras e de novos escravos indígenas.

No caso de Angola, Felipe II envia o licenciado João Morgado, para tomar informação e residência em $1583 .{ }^{15} \mathrm{E}$ em 1587 é criado o asiento do comércio de escravos, passando por cima das doações feitas no reinado de D. Sebastião para o capitão-donatário Paulo Dias de Novais. ${ }^{16} \mathrm{O}$ tráfico de escravos para as Índias ocidentais deve ser feito a

11 LÓPEZ MEDEL, Tomás. Colonización de América: informes y testimonios (1549-1572). Madri, Consejo Superior de Investigaciones Científicas, 1990, p. 51.

12 Para ver o esboço de uma política indigenista no Regimento de Tomé de Sousa: THOMAS, G. Política indigenista dos portugueses no Brasil. São Paulo, Loyola, 1982, p. 220.

13 Ver "Capítulos que Gabriel Soares de Sousa deu em Madrid ao Sr. D. Cristovam de Moura contra os padres da Companhia de Jesus que residem no Brasil, com umas breves respostas dos mesmos padres que deles foram avisados por um seu parente a quem os ele mostrou" (1592). In: Anais da Biblioteca Nacional do Rio de Janeiro. Rio de Janeiro, Imprensa Nacional, 1942, vol. LXII.

14 Sobre a história do tribunal da Relação do Brasil, ver: SCHWARTZ, S. B. Burocracia e sociedade no Brasil colonial. São Paulo, Perspectiva, 1979.

15 “Regimento de D. Filipe I a João Morgado". Lisboa, 19 de agosto de 1583. In: BRÁSIO, Padre António (org.). Monumenta Missionaria Africana. Lisboa, Agência Geral do Ultramar, 1953-88, $1^{a}$ série, vol. IV, pp. 244-247 (a partir de agora abreviada por MMA). "Regimento ao Provedor da Fazenda". Lisboa, 27 de outubro de 1583. In: MMA, 1, vol. XV, pp. 3-7. "Alçada ao Licenciado João Morgado”. Lisboa, 14 de janeiro de 1584. In: MMA, 1, vol. IV, pp. 262-264.

16 Segundo SCHWARTZ, S. B.: "Dias de Novais tornou-se capitão e donatário de Angola com poderes judiciais equivalentes àqueles concedidos aos donatários brasileiros entre 1530 e 1540”. Op. cit., p. 15. “Carta 
partir de Sevilha. Em 1592 a Coroa cria o governo geral para Angola. O objetivo é cessar a conquista, etapa marcada pela delegação do poder real aos conquistadores que iniciam a ocupação das terras e sua exploração econômica. Nesta etapa, os conquistadores se apropriam do dominium sobre a mão-de-obra e este é o fundamento de sua autonomia política e econômica em relação a Coroa. Portanto, conter o processo de conquista significava substituir o sistema de dominium pessoal pelo de dominium político, em que todos (conquistadores e nativos) devem reconhecer a real potestad, o soberano. A principal medida exigida do primeiro governador geral de Angola, D. Francisco de Almeida, é a suspensão das doações de terras e sobas (chefes locais) feitas por Paulo Dias de Novais aos conquistadores e jesuítas. Os sobas deveriam ser vassalos do rei que receberia impostos pagos em escravos em troca de apoio militar, comércio e o conhecimento da fé católica. A Coroa procura se apropriar do tráfico de escravos em duas dimensões: a partir do fim do dominium pessoal (o sistema de amos) e a vinculação dos sobas ao poder real, e com o desenvolvimento do negócio escravista na lógica do capitalismo comercial.

As reações em Angola são imediatas e recordam as antigas rebeliões dos colonos do Peru em 1542 contra as Leyes Nuevas. ${ }^{17}$ Os conquistadores exigem a manutenção do dominium sobre os sobas, prendem o governador e o mandam de volta a Portugal. Os conquistadores põem outro governador que revoga a lei real. ${ }^{18}$ Entre as forças que se opuseram a Coroa estavam os jesuítas. Apesar das medidas reais, as sociedade novas ${ }^{19}$ surgidas no processo de conquista da América e da África possuem uma articulação atlântica. E se a Coroa pretende fazer frente a esta, necessita atuar no mesmo contexto geopolítico.

Aqui está a originalidade da política ultramarina no reinado de Felipe III, pela primeira vez a Coroa atua simultaneamente no Brasil e em Angola. O sentido desta atuação é o fortalecimento do aparato político-administrativo, representado pelo governo geral e pelo tribunal da Relação do Brasil; um maior controle do negócio escravista e sua vinculação a política indigenista na América. A Coroa procura romper com o dominium dos conquistadores e dos jesuítas sobre os indígenas e os africanos. Estas medidas representam

de doação a Paulo Dias de Novais". Lisboa, 6 de setembro de 1571. In: ALBUQUERQUE, Luís de (dir.). Angola no Século XVI. Lisboa, Publicações Alfa, 1989, pp. 69-82. O conquistador Dias de Novais faleceu em 1589, o asiento com Pedro de Sevilla e Antonio Mendez de Lamego, foi concertado em Lisboa, no dia 28/7/1587: "Un Assiento des fermes D’Afrique”. In: SCELLE, Georges. La traite négrière aux Indes de Castille. 2 vols., Paris, Librairie de la Societé du Recueil, J. -B. Sirey \& du Journal du Palais, 1906, pp. 790794.

17 ALENCASTRO, L. F. de. Op. cit., p. 21.

18 Angola, 10 de junho de 1593, in: MMA, 1, p. 466, vol. III.

19 "Efetivamente, ao se transitar do comércio para a colonização, passava-se da comercialização de bens produzidos por sociedades já estabelecidas para a produção de mercadorias e montagem de uma sociedade nova”. NOVAIS, Fernando A. Estrutura e dinâmica do antigo sistema colonial. São Paulo, Brasiliense, 1998, p. 29. 
uma tentativa de refundação da colonização baseada no escravismo e na conexão entre o Brasil e Angola.

A formação dos Estados modernos no contexto da expansão do capitalismo comercial e seus desdobramentos coloniais revelam a necessidade do Estado de controlar as relações com a mão-de-obra. Não pode existir dominium político, soberania do rei sobre suas colônias e vassalos, sem a regulamentação do trabalho indígena ou africano. Por outro lado, houve uma vinculação da política indigenista ao tráfico de escravos. A desterritorialização da mão-de-obra foi um importante fator de dependência dos colonos em relação à metrópole. De tal forma, que no momento das independências na América latina, a permanência do estatuto colonial no caso de Cuba, ou a da dinastia real portuguesa no Brasil, dependem de um compromisso para manter o tráfico e a escravidão nesses territórios.

Não podemos pensar os processos de independência sem, a curto prazo, tratar do tema da participação dos indígenas e dos negros nas guerras de emancipação, e sem, a médio e longo prazo, tratar o problema da mão-de-obra, e a necessidade de se repensar o lugar dos negros e indígenas na nova organização política.

\section{Barbados Act e as contradições aparentes do Code Noir}

A legislação inglesa em relação ao governo dos escravos foi feita diretamente pelos planters das Antilhas britânicas. ${ }^{20}$ É o caso do Barbados Act for the better ordering and governing of Negroes de 1661. Esse código, elaborado pela Assembléia local, reagia ao crescimento das tensões escravistas nas ilhas antilhanas. Penalizava: a "fuga, roubo de valores elevado, incêndio culposo, estupro e assassinato, delitos considerados crimes capitais, envolvendo quase sempre a execução do escravo com indenização do proprietário pelo Estado". No caso de rebelião contra a ordem branca: "aplicação pública da pena de morte e do suplício dos corpos dos condenados". ${ }^{21}$ A Coroa inglesa, portanto, não interferia nas relações entre senhores e escravos. A preocupação dos códigos para as Antilhas inglesas era o controle social dos escravos e preservava os direitos de propriedade dos colonos.

Já no édito real de 1685, conhecido como Code Noir, a legislação colonial francesa interferia profundamente nas relações entre senhores e escravos. Este modelo de interferência da Coroa no dominium pessoal dos colonos tem grande influência da política

20 Ver também MARQUESE, Op. cit., pp. 41-46.

21 Ibidem, p. 41. 
Habsburgo. ${ }^{22}$ A preocupação felipina com o governo dos indígenas e as primeiras leis que pretendiam interferir no trabalho africano passam a tratar exclusivamente do governo dos escravos negros. $^{23}$

O Code Noir possui uma contradição aparente que revela a dificuldade em distinguir o dominium pessoal exercido pelos senhores sobre os seus escravos e o dominium político dos mesmos que deveria ser de responsabilidade do Estado. No artigo 26 o código permite que os escravos, ou terceiros, denunciem seus senhores "ce que nous voulons être observé pour les crimes et traitements barbares et inhumains des maittres envers leurs esclaves". ${ }^{24}$ No entanto, nos artigos 30 e 31 o código deslegitima a atuação dos escravos como agentes ou testemunhas de justiça. Seria uma contradição do Code Noir? Marquese observa nesse documento aquilo que Michel Foucault definiu como "governamentalidade":

\begin{abstract}
“entre os séculos XVI e a primeira metade do XVIII, houve, na literatura sobre a arte de governar produzida na Europa ocidental, uma estreita articulação conceitual entre os atributos do governo do Estado absolutista e os demais governos existentes no reino (governo da família, das almas, das ordens religiosas etc.)".25
\end{abstract}

Ainda não estava definida a separação entre o dominium senhorial e o dominium político. Inclusive porque a Coroa ainda possuía vastos poderes patrimoniais. Os conquistadores da América ou da África partiam de seu dominium pessoal sobre indígenas e africanos para constituir seu dominium político local. Portanto, qualquer interferência da Coroa no âmbito da regulamentação das relações com a mão-de-obra sofria forte resistência. Yvan Debbash observa que essa ambivalência do Code Noir garante a permanência da "soberania doméstica". ${ }^{26}$ No entanto, tanto Debbash como Marquese não

22 Fundamentada nas obrigações do rei com os povos sujeitos a sua Coroa, no primado da religião católica, e no direito romano.

23 As ilhas atlânticas, ou antilhanas, permitiram o desenvolvimento de um projeto de colonização muito distinto dos espaços continentais. A maior parte dessas ilhas tinha escassa população nativa, o que permitiu levar a experiência colonial, baseada no escravismo africano, a suas últimas consequências. Para o início da colonização européia no Atlântico deve-se analisar o caso de São Tomé. A instabilidade dessas sociedades também se revelou desde o princípio, ver: SANTOS, Catarina Madeira. "A formação das estruturas fundiárias e a territorialização das tensões sociais: São Tomé, primeira metade do século XVI”. Revista STVDIA, nº 54/55, 1996, pp. 51-91. A partir da derrota holandesa no nordeste brasileiro, a meados do século XVII, ocorre a ocupação e estabelecimento das novas plantations nas Antilhas. Franceses e ingleses vão seguir o exemplo holandês na região. Finalmente, o desenvolvimento de Cuba no final do século XVIII, também revelará as particularidades das plantations insulares em relação às do continente.

24 Sobre o Code Noir ver: DEBBASH, Yvan. "Au coeur du 'gouvernement des esclaves', la souveraineté domestique aux Antilles françaises (XVIe-XVIIIe siècles)". Revue Française d'Histoire d'Outre-Mer. LXXII, $n^{\circ}$ 266, 1985, pp. 31-54. SALA-MOLINS, Louis. Le Code noir, ou le calvaire de Canaan. Paris, PUF, 1987. Essa inversão na argumentação nos lembra os depoimentos do padre Manoel da Nóbrega, primeiro provincial dos jesuítas no Brasil, que resposabilizava a desordem colonial pela ambição e soberba dos conquistadores, ver: ZERON, C. A. Op. cit., pp. 44-171.

25 MARQUESE, Op. cit., p. 38.

26 DEBBASH, Op. cit., pp. 31-54. 
analisam essa ambivalência do ponto de vista estrutural. Atribuem essa a uma idéia monolítica de Antigo Regime sem analisar o período como momento de transição e de constituição da soberania política. ${ }^{27}$ Aliás esse é um problema geral da historiografia, que ao analisar textos jurídicos costumam atribuir características como: ambivalência, ambiguidade, contradição, etc. e acabam por relativizar seus conteúdos políticos.

Essa foi a diferença fundamental entre a legislação inglesa e a francesa sobre o governo dos escravos. Na primeira não existe nenhuma interferência do Estado que preserva o direito de propriedade e de exploração da mão-de-obra. A escravidão é um negócio, e os planters têm poder absoluto sobre ele. No caso francês o Estado interfere no negócio e tem a escravidão como elemento que favorece a criação de súditos, que reconheçam a soberania do rei, o único soberano. Determina uma série de obrigações do senhor, justificado pelo catolicismo e pelo direito romano. Mas essas medidas convivem com uma contradição estrutural: o direito sobre o asiento de escravos não é um direito patrimonial da Coroa? A Coroa não tem escravos? E fazendas com escravos? Enfim, a Coroa também fundamenta seu poder no sentido duplo da palavra dominium.

A soberania não podia plasmar-se enquanto estivesse fundamentada no dominium patrimonial. Era necessário acabar com a servidão e com a escravidão, e o conceito de patrimônio deveria ser substituído pelo de propriedade privada.

\section{Reformas coloniais e a lição de São Domingos}

As comparações entre os distintos modelos de governo dos escravos começaram no final do século XVIII. O escritor Edward Long, em seu livro The history oj Jamaica de 1774, atribuiu uma superioridade da administração francesa da escravidão em relação à experiência inglesa. ${ }^{28}$ Os motivos eram a intervenção do Estado francês no governo privado dos escravos e a preocupação católica com a evangelização dos negros. Edward Long reconhecia a importância da interferência do Estado na relação entre senhores e escravos. Nas décadas de 1760 e 1780 chegou-se a um consenso sobre o tema e até Adam Smith reconhece, mesmo condenando a escravidão, a superioridade do sistema francês frente ao inglês. ${ }^{29}$

\footnotetext{
27 No caso das historiografias brasileira e portuguesa essa visão é o resultado de uma leitura estreita da obra de HESPANHA, António M. "Para uma teoria da história institucional do Antigo Regime". In: Poder e instituições na Europa do Antigo Regime. Lisboa, Fundação Calouste Gulbenkian, 1984.

28 MARQUESE, Op. cit., pp. 106-128.

29 SMITH, Adam. A riqueza das nações - investigações sobre sua natureza e suas causas. São Paulo, Nova Cultural, 1996, pp. 83-84.
} 


\section{Reformas pombalinas: a ilustração lusitana no espaço colonial}

No reinado de D. José I, e com a escolha do futuro marquês de Pombal como braço direito, iniciaram-se as reformas do império português. Para o caso que interessa nesse trabalho devemos destacar a criação das companhias monopolistas de comércio e as medidas relacionadas ao tráfico de escravos, novamente associadas a uma política indigenista. Essas medidas são particularmente interessantes de serem analisadas para o Norte do Brasil. O objetivo era inserir o sistema das plantations na região. A Companhia Geral do Grão-Pará e Maranhão, criada em 1755, detinha o monopólio do tráfico de escravos e favorecia o surgimento de economias agrícolas exportadoras. A Companhia privilegiava os comerciantes da praça de Lisboa, em detrimento da crescente presença dos ingleses e outros estrangeiros no comércio com o Brasil. Além disso foi decretada a liberdade indígena (1753-1755) e foram criados mecanismos institucionais para proibir a escravidão dos mesmos. Essas leis atingiram os proprietários de escravos índios e os jesuítas, que acabaram sendo expulsos em 1759: a tutela passava para as mãos do Estado através do Diretório dos Índios.

As medidas pombalinas possuem uma relação evidente com a política ultramarina de Felipe II e Felipe III: as medidas atuam simultaneamente na África e na América; decretando a liberdade indígena e criando um aparato político-administrativo para garantir a mesma; favorecendo a expansão do tráfico negreiro, o Estado concede o monopólio vinculado a praças mercantis específicas. Outro paralelo interessante está relacionado à política da Coroa em relação aos jesuítas. Em relação à aliança entre D. Sebastião e os jesuítas no processo de colonização do Brasil, Felipe II reagiu ao monopólio jesuítico sobre a questão indígena. Nesse contexto, reconheceu a importância dos inacianos na intermediação das relações entre colonos e indígenas, mas procurava subordiná-los, a partir de diferentes medidas, ao poder real. A expulsão dos jesuítas em 1759 se insere nesse processo de longa duração e está relacionado ao processo de formação dos Estados modernos e a reafirmação da soberania real. Os logros das reformas políticas de Pombal foram muito limitados. Além dos interesses da elite luso-brasileira, os comerciantes ingleses e outros estrangeiros já controlavam grande parte do comércio do Brasil.

O discurso econômico relacionado à administração dos escravos apareceu no império português no último quarto do século XVIII. As reformas pombalinas provocaram a substituição dos quadros religiosos nas universidades portuguesas e se difundiu o pensamento ilustrado. Este criticava a interferência do Estado na economia e exortava os senhores a tratarem melhor seus escravos para o benefício da metrópole. Essa foi a 
particularidade das medidas portuguesas em relação à mão-de-obra. Apesar de vincular o tráfico negreiro à proibição da escravidão indígena, de expulsar os jesuítas, de favorecer os comerciantes nacionais com o estabelecimento de companhias monopolistas, a laicização universitária permitiu a recepção do pensamento liberal inglês. A elaboração de um saber econômico sobre a escravidão condena a interferência do Estado no dominium privado do senhor sobre sua propriedade.

\section{Escravidão nas Antilhas inglesas: entre o dominium senhorial e a propriedade privada}

$\mathrm{Na}$ Inglaterra se formavam os primeiros grupos de pressão que condenavam a escravidão e exigiam sua abolição. ${ }^{30}$ Os debates foram intensos e um bom exemplo foi o de James Ramsay e James Tobin. Ramsay denunciou o mau tratamento que tinham os escravos no Essay on the treatment and conversion of African slaves in British sugar colonies, de 1784. Seus argumentos foram rebatidos por Tobin em Cursory remarks upon the reverend Mr. Ramsay's essay de 1785.

O que está evidente é que o debate estava posto na ordem do dia e os escravistas não tinham nenhum problema de apresentar seus argumentos publicamente. Muitos denunciavam as condições dos operários da indústria têxtil inglesa para justificar a escravidão. As pressões políticas e a opinião pública também estimularam mudanças nos discursos dos senhores e em suas atitudes frente ao governo dos escravos. Aumentou a preocupação com a saúde dos escravos (alimentação, vestuário e moradia), houve uma maior racionalização do trabalho e desenvolveu-se a idéia de reprodução dos escravos nas próprias colônias. Também favoreceu os discursos paternalistas sobre a escravidão e a antiga associação da relação senhor-escravo com a do pai-filho. ${ }^{31}$ Em 1792 o Consolidated Slave Act of Jamaica, feita pelos próprios planters, determinava uma série de medidas em relação ao governo doméstico dos escravos.

Marquese chama a atenção para uma mudança importante na argumentação dos senhores de escravos antilhanos no final do século XVIII:

\footnotetext{
"Ao operarem com categorias retiradas do discurso econômico instalado nas ciências morais (trabalho e produção), e ao incorporarem vários dos elementos da
}

\footnotetext{
30 Em 1787 foi criada a Sociedade pela Abolição do Tráfico na Inglaterra. No caso francês apesar da condenação da escravidão que passou por Jaucourt (década de 1760), pelos fisiocratas (décadas de 1760-1770) e por Condorcet e Frossard (anos 1780), a mobilização contra a escravidão nunca teve proporções de um movimento de massa. Ver: MARQUESE, Op. cit., pp. 109-110 e 119.

$31 \mathrm{O}$ paternalismo das relações escravistas ficam evidentes no livro de EDWARDS, Bryan. History, civil and commercial, of the British colonies in the West Indies. Londres, John Stockdale, 1794.
} 
sensibilidade das Luzes, os autores franceses e ingleses puderam construir uma teoria laicizada sobre a administração dos escravos nas 'plantations' antilhanas". ${ }^{32}$

O discurso legitimador da escravidão se desloca da religião para a economia. Os senhores de escravos passam a defender seu dominium sobre os mesmos na lógica da propriedade privada. Essa nova argumentação conciliava humanidade e interesse. A constituição do discurso da economia política permitiu pensar isoladamente na categoria trabalho. E, consequentemente, na produtividade do trabalho. Além da preocupação com o corpo do escravo começaram a investigar suas motivações, as formas de preservação da sua saúde, os métodos punitivos e os estímulos para o trabalho.

\section{As Ordennances e a obediência ameaçada}

$\mathrm{Na}$ França, as Ordennances de dezembro de 1784 e dezembro de 1785, determinavam a consolidação das leis que interferiam no dominium dos senhores sobre seus escravos e criavam em âmbito local um tribunal responsável pela aplicação destas leis. Existe uma relação clara com as medidas felipinas da passagem do século XVI para o XVII. Os habitants franceses contestaram essa interferência e resistiram a implementação das Ordennances.

O questionamento destas medidas feitas pelo proprietário de São Domingos, Stanislas Foäche, caracteriza de forma exemplar a dimensão política que envolvia a escravidão: "como conter os negros se eles podem acusar os brancos? Todo laço de obediência é rompido". ${ }^{33}$ A Coroa, ao intervir no dominium dos senhores sobre seus escravos, criava a possibilidade dos escravos questionarem esse mesmo dominium. A última frase de Foäche é uma ameaça velada: se os escravos podem questionar o dominium que os senhores exercem sobre eles, os senhores também questionarão o dominium que a Coroa exerce sobre a colônia. Toda a hierarquia que constitui os vínculos de dependência política do Antigo Regime está ameaçada. A contradição aparente evoluiu para a negação do próprio sistema. O questionamento da soberania real e a crise do Antigo Regime também partem da América.

A criação da Assembléia Nacional em 1789 estimulou os debates e a mobilização política nas colônias francesas. Em São Domingos, os proprietários reivindicavam maior autonomia em relação ao poder da metrópole, enquanto, que a população pobre e livre exigia maior participação naquela sociedade. Os eventos precipitados na metrópole e nas colônias levam ao questionamento do dominium em todos os seus níveis: a soberania da 
Coroa sobre os colonos, o dominium dos senhores sobre seus escravos e seu poder local. Em 1791 se inicia a revolução de São Domingos. ${ }^{34}$

O que esta revolução deixou evidente é que havia um tênue equilíbrio de poder nas sociedades coloniais escravistas. Por um lado a exigência das elites locais contra a pressão crescente da metrópole sobre suas colônias, particularmente contra a interferência da Coroa no dominium sobre os escravos. Por outra parte, muitos grupos de homens livres estavam excluídos da participação política e do acesso a propriedade. O reformismo ilustrado da segunda metade do século XVIII aumentava a pressão sobre a produção e a realidade colonial, procurando consolidar sua soberania. No entanto, quando a Coroa negou o dominium patrimonial dos senhores sobre seus escravos ela abriu a possibilidade para o questionamento de seu próprio poder. Grande parte dele estava baseada no poder patrimonial. A crise do sistema colonial revelava seu aspecto político. A ruptura com o sistema de dominium criava a possibilidade de novas rupturas: "todo laço de obediência é rompido".

Portanto o vazio de poder viabilizava a emergência de novos projetos de soberania e dominium nas colônias. Os senhores queriam instituir uma nova soberania política nos espaços coloniais e se dão conta que os grupos excluídos desta sociedade também exigiam representação na mesma. A reação era em cadeia: tratar o tema da soberania política implicava tratar o dominium senhorial. A ruptura do sistema social escravista calou fundo no imaginário colonial e foi o grande terror dos senhores de escravos até bem avançado o século XIX. Esse vínculo intrínseco entre soberania do Estado e o fim da escravidão também ficaram evidentes no desenvolvimento da Revolução francesa. Com a sua radicalização os jacobinos decretam o fim da escravidão nas colônias francesas em fevereiro de 1794.

\section{O pacto entre a Coroa espanhola e a elite habaneira: preservando antigos domínios}

O sentido geral das reformas borbônicas reforçou o aparato político-administrativo, que aumentava o controle sobre as colônias, e a liberalização do comércio. Essas reformas, seguindo a tradição imperial espanhola e influenciada pelos códigos franceses sobre o governo dos escravos, também foram radicais no que se referia ao dominium dos colonos sobre indígenas e africanos. A implementação dessas medidas, no entanto, revelaram os limites da Coroa na interferência sobre o dominium senhorial nas colônias.

34 Sobre a Revolução de São Domingos ver nota 8. 
Uma série de leis reitera a proibição da escravidão indígena. Os jesuítas foram expulsos em 1767 e seus bens confiscados pela Coroa. ${ }^{35} \mathrm{O}$ primeiro conjunto de leis sobre o governo dos escravos do período foi elaborado em São Domingos. ${ }^{36}$ O objetivo era equiparar o lado espanhol da ilha ao dinamismo da parte francesa, que produzia $30 \%$ do açúcar mundial. Feito pelo Cabildo, o documento revela o projeto senhorial para o governo dos escravos. A preocupação é a fuga para as propriedades de libertos ou brancos pobres, chamados "conucos" ou "labranzas". ${ }^{37}$ Os senhores são amos e o documento é a defesa do dominium senhorial, embora preveja a punição de senhores displicentes. $\mathrm{O}$ artigo $30^{\circ}$ prevê até 300 chicotadas aos negros ou negras ausentes do serviço de seus amos. ${ }^{38}$

Em 1783, o rei pedia que o Código Negro francês fosse adaptado para a ilha de São Domingos. ${ }^{39}$ Em 1784 foi abolida a marca dos escravos ${ }^{40}$ e ficou pronto o Código Negro para a parte espanhola de São Domingos. ${ }^{41}$ Portanto, a Coroa pretendia superar a regulamentação feita pelos senhores de escravos e subordinar o dominium senhorial ao dominium político da Coroa. As reformas se iniciaram em São Domingos e foram quase simultâneas a implementação das Ordennances no lado francês da ilha. A principal influência era o Code Noir francês, e em homenagem a Carlos III, foi chamado de Código Negro Carolino. A Coroa interfere profundamente no governo dos escravos (que sempre deve ser associado ao governo dos colonos): tanto no controle social como no dominium exercido pelos seus senhores.

O código trata do governo econômico e político dos escravos dentro de um novo contexto histórico e que, portanto, necessita um novo conjunto de leis. A instrução é uma síntese das preocupações com o governo privado dos escravos e o governo do Estado sobre a colônia. O conceito de economia política sintetizava essa idéia.

"Siendo, pues, la felicidad, utilidad y seguridad del Estado, (consideradas bajo sus principales y respectivas miras), las partes que constituyen su buen Gobierno, serán

35 A Coroa também exerceu dominium senhorial sobre os escravos, ver: "Capítulos del reglamento de esclavos para las haciendas de Santa Gertrudis de Motocache, San Jacinto y San Jose de la Pampa, confiscadas a los jesuitas". Motocache, 17 de agosto de 1772. In: LUCENA SALMORAL, Op. cit., pp. 1016-1018.

36 "Ordenanzas para ocurrir a la deserción, sujeción y asistencia de los esclavos". Santo Domingo, 25 de abril de 1768. Ibidem, pp. 989-999.

37 Assim descreve o documento: "alienta e induce el abrigo y protección que hallan en el crecido número de negros libertos, que viven regularmente en los campos, sin instrucción alguna, con lastimosa libertad y en grave daño nuestro (...)." Ibidem, p. 991.

38 Ibidem, p. 995.

39 "Real Cédula encargando al gobernador y audiencia dominicanos un código negro". Madri, 23 de dezembro de 1783. Ibidem, pp. 1026 e 1027.

40 "Real orden aboliendo la práctica de marcar a los negros esclavos en el rostro o espalda" [el carimbo]. San Lorenzo, 4 de novembro de 1784. Ibidem, pp. 1027 e 1028.

41 "Código de legislación para el gobierno moral, político y económico de los negros de la Isla Española" [Código Negro Carolino]. Santo Domingo, 14 de dezembro de 1784. Ibidem, pp. 1028-1094. 
también el norte de nuestras Leyes en cuanto puedan contribuir a su importante logro. La ocupación útil y asidua de los negros libres y esclavos en el cultivo de las producciones que necesita la Metrópoli, su división oportuna en clases y razas, los ministerios y oficios a que deban aplicarse". ${ }^{42}$

A escravidão e os frutos do trabalho escravo devem servir aos interesses da metrópole, não mais aos interesses econômicos do seu senhor. Portanto, o governo dos mesmos deve estar subordinado aos interesses do Estado, "a los Dominios de S.M" ${ }^{43}$ É muito interessante observar que para os séculos XVI e XVII os termos 'colonos' e 'colônia' eram evitados na documentação régia. Esses conceitos ainda tinham o sentido romano associado à autonomia das cidades no império. A ilustração colonialista transformou o significado dessas palavras, reafirmando o sentido de conformação aos interesses da metrópole. $^{44}$

A Coroa conciliava os preceitos católicos da educação dos escravos com os valores morais relacionados ao trabalho e a obediência aos brancos, sintetizados pelo conceito de "polícia”. A boa ordem social da colônia também dependia de uma divisão clara entre os escravos, libertos, mulatos, etc. Esses últimos deveriam cumprir um papel fundamental no domínio dos cativos. Nesse sentido, as demandas dos homens brancos pobres, libertos e mulatos por maior participação nas sociedades escravistas eram duramente combatidas e a lei prescreve uma série de normas para controlar os homens livres. ${ }^{45}$ Como reagiria esse grupo a essas medidas? Os "proprietários zeladores" deveriam controlar essa classe social e todas as atividades dos escravos.

O documento também reconhece a importância dos negros na segurança das colônias:

\footnotetext{
“(...) siendo de la mayor importancia a la seguridad interior y exterior de la Isla, su amor y adhesión a ella, pues su poderosa influencia ha preservado en muchas ocasiones importantes Provincias a la Corona Española". ${ }^{6}$
}

Interessante pensar que esse reconhecimento por parte da Coroa, da importância dos negros na defesa das colônias, já havia sido feito para o caso indígena, momentos antes da interferência da Coroa no governo dos gentios e na definição da liberdade indígena que tanta resistência sofreu por parte dos colonos. Os colonos podem ter percebido um paralelo entre essas medidas? Temiam a interferência da Coroa no seu dominium?

\footnotetext{
42 Ibidem, p. 1030.

43 Ibidem, p. 1031.

44 Tal como analisamos na nota 9.

45 "Por tanto, todo negro esclavo o libre, pardo primerizo o tercerón, y en adelante, será tan sumiso y respetuoso a toda persona blanca, como si cada una de ellas fuera su mismo amo o señor del siervo". Ibidem, p. 1035. 46 Ibidem, p. 1031
} 
Além de condenar o dominium senhorial exercido a partir da violência ("abusos y desórdenes”), o documento opõe esse método ao do bom governo moral dos escravos.

\begin{abstract}
“(...) siendo pues el objeto más importante de su buen régimen y administración asegurar sólidamente a la Isla Española y al Estado su tranquilidad y sosiego interior y exterior, se hace necesario desarraigar de su corazón tan vehementes nativas inclinaciones, sustituyendo en él las benéficas de la lealtad al soberano, del amor a la Nación Española, del reconocimiento y gratitud a sus amos, de la subordinación a los blancos, respeto y veneración a sus padres, parientes y ancianos, sensibilidad y correspondencia con sus amigos, y demás virtudes sociales". ${ }^{47}$
\end{abstract}

Essa passagem reconstrói as relações de poder no contexto da escravidão, e os negros devem submeter-se a "lealtad al soberano", ao "amor a la Nación Española" e a partir desta ao dominium senhorial. O documento primeiramente faz referência a Nação Espanhola, mas na continuação trata os escravos como nação, que são retirados violentamente de sua "Pátria amada". Esse elemento não é menos relevante, a África se transforma em pátria querida, com tradições e liberdades próprias, de onde os negros são retirados com violência e submetidos a escravidão. Os conceitos de independência e liberdade sempre têm sentido negativo no texto.

A repercussão das reformas borbônicas foi diferenciada de acordo com as características de cada região do império colonial. ${ }^{48}$ No caso de Cuba, as reformas borbônicas foram positivas para a elite habaneira. ${ }^{49}$ Estas elites foram capazes de negociar com a metrópole e tiveram uma série de privilégios que garantiu a permanência do estatuto colonial.

Allan Kuethe deu novos elementos para entender esse pacto entre a Coroa e a elite habaneira. O autor destaca o acordo feito em 1763-65: em troca de recuperar Havana do domínio inglês foi estabelecido um novo sistema fiscal e abriu o comércio. ${ }^{50}$ Em segundo lugar, o autor destaca os benefícios sociais, honoríficos e a organização das milícias locais oferecidos pela Coroa a essa elite. ${ }^{51} \mathrm{~A}$ ilha era formada por uma elite dependente do capital comercial e dos interesses metropolitanos, possuía uma população onde a diferença da cor da pele definia a distinção sócio-política. A produção açucareira ainda não havia se

47 Ibidem, p. 1033.

48 ZEUSKE, M (coord.). Las transformaciones hacia la sociedad moderna en América latina: causas y condiciones en la economía, la política y las mentalidades. Actas del X Congreso AHILA, 1993, Leipzig/Köln, 1996.

49 Um trabalho pioneiro nesse sentido foi o de DOMÍNGUEZ, Jorge I. Insurrección o lealtad. La desintegración del Imperio español en América. México, Fondo de Cultura Económica, 1985.

50 Os ingleses haviam dominado a ilha graças a sua capacidade de oferecer braços para as plantations, em menos de um ano desembarcaram mais de 3 mil escravos em Havana. MARQUESE, Op. cit., p. 195.

51 KUETHE, Allan J. Cuba 1753-1815, Crown, Military and Society. Knoxville, The University of Tennessee Press, 1986. 
desenvolvido e a ilha era um ponto estratégico dos interesses coloniais na região. Em 1764 acabou o monopólio comercial de Cádiz, ocorreu a isenção de impostos de produtos cubanos, o fim dos monopólios de açúcar, da madeira e a liberdade para o tráfico negreiro. O decreto real de outubro de 1765 liberalizava definitivamente o comércio. Também foram estabelecidos os impostos de alcavalas e almoxarifado, se transformou o aparato da real fazenda e se estabeleceu a intendência de Havana. Essas reformas deram resultados quase imediatos, aumentando a arrecadação da cidade. A liberalização também legalizou o comércio de contrabando, endêmico em muitas regiões e fez de La Habana o principal porto reexportador do império. ${ }^{52}$

Finalmente a economia cubana obteve uma política negreira privilegiada que garantiu a mão-de-obra necessária para a expansão da economia açucareira. A política de Carlos III tentava nacionalizar o tráfico de escravos a partir da concessão de exclusividade a Compañía del Asiento de Negros ou Compañía Gaditana. ${ }^{53} \mathrm{Na}$ real cédula de 29 de fevereiro de 1789 o comércio de escravos foi liberalizado. ${ }^{54}$

Em 1791 a revolução do Haiti teve muitos impactos sobre a ilha. Primeiro por ser a maior produtora de açúcar do mundo, segundo porque muitos buscaram refúgio em Cuba e, finalmente, pelo medo da rebelião negra. Enquanto isso na Corte, o jovem representante de La Habana, Francisco Arango y Parreño, obteve a real cédula de 24 de novembro de 1791 que: prorrogava a livre introdução de escravos negros na ilha e permitia aos cubanos negociar o açúcar em qualquer porto da América e da Europa. Essas medidas foram ampliadas em 1792. Arango y Parreño teve o apoio dos responsáveis pela Fazenda Real e da Junta de Comércio que superaram as resistências do Conselho das Índias. ${ }^{55}$ Ameaçada pelas rupturas com o dominium político e com o dominium escravista ocorridas em São Domingos, a Coroa estabelece um acordo com as elites locais: legitima e garante o fornecimento de mão-de-obra africana, aceita o dominium dos senhores sobre seus escravos em troca da continuidade do sistema colonial.

52 Ver os trabalhos de AMORES CARREDANO, Juan B. "La intendencia de La Habana en la etapa de las reformas borbónicas (1765-1790)". In: ZEUSKE, Michael (coord.). Op. cit. "Francisco de Arango y Parreño: la transición hacia la modernidad en Cuba". In: FISCHER, John (ed.). Actas del XI Congreso Internacional de AHILA. Liverpool, 1998, pp. 507-522, vol. II. Ver do mesmo autor: "La elite cubana y el reformismo borbónico", In: LATASA, Pilar (coord.). Reformismo y sociedad en la América borbónica : In memoriam Ronald Escobedo. Barañain, EUNSA, 2003.

53 Sobre as diferentes fases dos asientos de escravos ver: SCELLE, Op. cit. Para um estudo pormenorizado da Companhia Gaditana, ver: TORRES RAMÍREZ, Bibiano. La Compañía Gaditana. Sevilha, Escuela de Estudios Hispano-Americanos, 1973. Ver também MAURO, Fréderic. Portugal, o Brasil e o Atlântico. 2 vols., Lisboa, Editorial Estampa, 1989. LUCENA SAMORAL, Op. cit.

54 "Real Cédula concediendo la libertad para el comercio de esclavos en las Antillas mayores y Caracas". Madri, 28 de fevereiro de 1789. Ibidem, pp. 1144-1147.

55 Ver AMORES CARREDANO, Juan B. "El joven Arango y Parreño: origen del proyecto políticoeconómico de la sacarocracia habanera (1786-1794)". Temas Americanistas, 12, 1995, pp. 12-17. 
A manutenção do sistema escravista no Brasil e em Cuba exigiu a continuidade da soberania política: colonial ou monárquica. Enquanto que nos outros países americanos a adoção de um novo regime político e um novo princípio de legitimidade e soberania levava, inexoravelmente, a abolição da escravidão.

\section{Liberdade! Para quem fazer o quê? - Independência e escravidão nos E.U.A}

A independência dos E.U.A colocou pela primeira vez a possibilidade de emancipação política nos contextos americanos. É interessante pontuar alguns aspectos da realidade norte-americana do final do século XVIII até a primeira metade do XIX. ${ }^{56}$

Ira Berlin estima que a população escrava dos E.U.A. passou de 697.897 em 1770 para 3.953.760 em 1860. Este grande aumento da população escrava fez dos E.U.A. a maior concentração escravista do Novo Mundo. ${ }^{57}$ Um tema muito analisado foi a contradição entre o pensamento liberal e a escravidão no século XIX. ${ }^{58}$ A reflexão de Vitor Izecksohn sobre os E.U.A. revela o contrário. Os estados do Sul, ainda escravistas, estavam mais preparados para a defesa da democracia que os estados do Norte. A razão era simples, no Sul, a constituição de uma legislação que excluía totalmente os negros da participação política acabava com os temores de luta de classe, coisa que no Norte representava uma grande ameaça. Esta realidade caracterizava o que John Ashworth denominou como igualitarismo racista. ${ }^{59}$

Os sulistas tentaram conciliar liberdade e escravidão utilizando um importante aspecto conservador da ideologia republicana. Eles proclamavam que a escravidão fortalecia o sentido de igualdade entre os homens brancos e a raça inferior, os negros, eram responsáveis pelo trabalho manual. Todo homem estava por cima dos escravos, e a cidadania estava restringida a comunidade dos brancos.

A oposição entre o Sul escravista e agrário, e o Norte industrial e free labor se tornou mais evidente com o grande desenvolvimento das indústrias do Norte nas primeiras décadas do século XIX. Este desenvolvimento criou um grande fluxo migratório para a região.

O Sul defendia uma política expansionista e escravista, neste sentido fizeram a conquista do Texas (1844) e de parte do México (1846-48). Com o surgimento do partido

56 IZECKSOHN, Vitor. "Escravidão, Federalismo e Democracia: a luta pelo controle do Estado nacional norte-americano antes da Secessão". In: Topoi, Rio de Janeiro, n.6, 2003, pp. 47-81.

57 FOGEL, R. e ENGERMAN, S. Time on the Cross: The Economics of American Negro Slavery. Boston, Little Brown and Company, 1974, pp. 3-12.

58 A obra mais importante para esse debate no Brasil é a de SCHUWARTZ, Roberto. Ao Vencedor as Batatas. Livraria Duas Cidades, São Paulo, 1977.

59 ASHWORTH, John. Slavery, Capitalism, and Politics in the Antebellum Republic. Nova York e Cambridge, Cambridge University Press, 1995, vol. 1. 
republicano em 1854, a posição contra a escravidão se tornou mais dura. A plantação escravista foi vista por seus partidários como o maior inimigo do desenvolvimento da nação e da sociedade. Este conflito levou a Guerra de Secessão, o que reitera a hipótese deste trabalho. A continuidade da escravidão impedia o desenvolvimento da soberania do Estado. O Estado nacional no contexto do capitalismo industrial não pode desenvolver-se ao lado do dominium pessoal exercido pelos senhores sobre os seus escravos. A liberdade individual, portanto, é a condição fundamental para que a soberania do Estado seja efetiva.

\section{Independência e escravidão na América latina}

A constituição de Bayona, 1808, tinha, pela primeira vez, a participação de deputados americanos. Os interesses de Napoleão na América estavam evidentes e desta forma legitimou politicamente seus representantes.

Neste contexto, a convocação das cortes de Cádiz também deveria ter representantes do ultramar. O representante do México, Guridi y Alcocer, ${ }^{60}$ em março de 1811, foi o primeiro a apresentar nas Cortes uma proposição abolicionista. Esta propunha: a proibição do tráfico e a abolição gradual da escravidão, o deputado fez uma crítica contundente a esta instituição. $\mathrm{O}$ México quase não utilizava mão-de-obra africana e, portanto $\mathrm{o}$ posicionamento deste deputado representava uma sociedade onde os indígenas e mestiços eram os principais trabalhadores. Foi publicada no dia 2 de abril de 1811 junto com uma moção de D. Augustín de Argüelles, esta por sua vez muito mais modesta, fazia referência à necessidade da abolição do tráfico.

No entanto, a Constituição silenciou sobre o assunto, apesar de haver criado uma comissão especial para o tema (a comissão estava formada por García Herreros, Mejía e Pérez Castro). O posicionamento dos representantes de Cuba foi decisivo para esse silêncio. D. Andrés Jáuregui chamou a atenção para que não se tratasse o tema da escravidão pelo perigo que supunha. Houve também a pressão do Ayuntamiento, do Consulado e da Sociedad Patriótica de La Habana, para não se tratar do tema. ${ }^{61}$ Dizia D. Francisco Arango y Parreño:

\footnotetext{
"V. M. señor, debe reconocer que el arrancar de su país a los infelices negros y mantenerlos aquí en la esclavitud en que se hallan no es obra de los particulares sino de los soberanos que nos pusieron en tal caso y de él no pueden sacarnos
}

60 "José Miguel Guridi Alcocer, conhecido como o cura de Tacubaya, foi um dos melhores oradores daquelas cortes, cuja presidência exerceu em 1812. Demonstrou uma ampla ilustração em todos os problemas americanos e nas reformas de Ultramar. Sacerdote muito respeitável, se caracterizou por seus ideais liberais". In: VILA VILAR, E. Op. cit. p. 392.

61 Informe de 20/7/1811: Ibidem, p. 394. 
precipitadamente decretando nuestra ruina y olvidando en un momento todo lo que se nos ha predicado y se nos ha mandado por más de 300 años". ${ }^{2}$

Este trecho deixa patente a relação entre a colonização e o envolvimento da Coroa com o sistema escravista atlântico. Também se observa o destacamento dos interesses coloniais em relação aos da Coroa, até um ponto em que se justifica a continuidade da escravidão como herança do sistema colonial. As pressões pelo fim da escravidão e o processo de independência na América contribuem para esta associação do sistema escravista como herança do sistema colonial. O liberalismo nas colônias enfatizou a argumentação do interesse e a melhoria da administração da mão-de-obra. Em outros casos, enfatizou os discursos paternalistas associados à evangelização dos negros.

O governador de La Habana, marquês de Someruelos, também informou às Cortes a comoção provocada pelo debate. Finalmente o Conselho de Estado, em 18 de novembro de 1812, se opos à abolição do tráfico: “(...) sobre todo por el transtorno que ocasionaría en la isla de Cuba". ${ }^{63}$ No dia $1^{\circ}$ de maio de 1813 se envia uma cédula às autoridades americanas para informar sobre o assunto.

A questão indígena não sofreu a mesma resistência por parte dos deputados americanos. Aceitaram a abolição da encomienda, do repartimiento e da mita. Depois de séculos de resistência, por que esta mudança no momento em que podem legislar sobre o assunto? Em muitas partes da América espanhola já estavam consolidadas outras modalidades de trabalho forçado em relação aos indígenas. Além disso, desde o século XVIII, a demografia indígena havia crescido e a oferta de mão-de-obra era muito mais relevante que nos séculos anteriores. A questão indígena em Cádiz também tem interesse especial. Os deputados americanos defenderam o reconhecimento dos indígenas como cidadãos. Isto fazia parte de uma estratégia política para que os americanos tivessem maior participação política. Mas, a participação efetiva dos índios será protelada nas realidades americanas.

No Congresso de Viena, 1815, os representantes de Portugal e Espanha, duque de Palmella y marquês de Labrador, se viram forçados a assinar um documento em que se comprometiam a acabar com o tráfico. D. José Garcia de León y Pizarro, primeiro Secretário de Estado, em seu memorial expõe sua intervenção no tratado anglo-hispano 
comentando as pressões inglesas de um lado e a dos cubanos, representados por Arango y Parreño, de outro. ${ }^{64}$

Em 1817, se assina o tratado com a Inglaterra pelo que sua Magestade Católica se obrigava a que o tráfico de escravos fosse abolido em todos seus domínios até 30 de maio de 1820, em troca de 400.000 libras. No entanto, Fernando VII inventa uns passaportes que se despacham em Cádiz a todo barco espanhol que quisesse fazer uma viagem para a África. De janeiro de 1817 ao final de fevereiro de 1818: 59 embarcações foram de La Habana até as costas africanas. ${ }^{65}$ Foram criados tribunais mistos em La Habana e Serra Leoa, mas que só atuaram a finais de 1820 .

No caso de Brasil, o evento fundamental que vai conformar o processo de independência e o tema da escravidão foi a transferência da Corte portuguesa ao Rio de Janeiro, em 1808. Fugindo da invasão napoleônica, a corte estabelece a metrópole no Rio. A primeira medida foi a abertura dos portos ao comércio com as nações amigas. Terminava o exclusivo comercial, com uma presença crescente da Grã Bretanha. Entre os grandes comerciantes da praça do Rio de Janeiro estavam os escravistas. A Coroa teve que fazer acordos com estas elites locais.

Do ponto de vista político, o Congresso de Viena, exigiu o fim do sistema colonial e a elevação do Brasil a Reino Unido a Portugal. A Revolução do Porto, em 1820, foi uma ameaça em relação às liberdades do período. Os deputados na Assembléia constituinte em Portugal protestaram contra as tentativas de recolonização. ${ }^{66}$

O tratado de 28 de agosto de 1835 reafirmava o acordo de 1817 que determinava o fim do tráfico de escravos. Já entrado o século XIX, as plantações de cana não eram tão lucrativas em Cuba como em anos anteriores. O grupo de intelectuais cubanos - Saco, Varela, Delmonte ou Arango - antigos defensores da escravidão, viam os limites dela para solucionar os problemas da ilha, que necessitava de uma política de povoamento para substituir os escravos.

Os debates foram retomados em 1845. O deputado Olivan propôs seguir o modelo norte-americano de reprodução in loco dos escravos. Ainda havia muitos defensores da instituição escravista, o deputado Seijas reafirmou a necessidade da conservação das Antilhas que dependia da mão-de-obra negra, tinham que acudir a sua proteção. Assim também se expressa o Ministro de Estado:

64 LEÓN y PIZARRO, José García de. Memorias de José García de León Pizarro (1770-1835). Revista de Occidente, 2 vols., Madri, 1953.

65 Ibidem, p. 396.

66 JANCSÓ, István e PIMENTA, João Paulo G. "Peças de um mosaico (ou apontamentos para o estudo da emergência da identidade nacional brasileira)". Texto inédito. São Paulo, Universidade de São Paulo, 2000. 
"El gobierno no se ha ocupado de formar ninguna ley ni reglamento para la uniformidad de la esclavitud en las Antillas; al contrario, ha expresado que la cuestión de esclavitud queda separada de la presente. Lo que tenga que hacer para asegurar es propiedad, que debe respetarse como cualquier otra, serán medidas que el gobierno tomará detenidamente a su tiempo; pero desea que no se complique una cuestión con otra. La cuestión de la esclavitud, como ha dicho muy bien el Sr. Olivan, no es igual a la del tráfico de negros, y la que ahora nos ocupa no es ni aun la de ese tráfico, sino la ley penal para los contraventores de los tratados". ${ }^{67}$

O combate ao tráfico negreiro atingiu seu ápice em meados da década de 1850, o preço dos escravos subiu de maneira exponencial. Nos E.U.A., a manutenção da escravidão depois da independência criou uma contradição interna, territorializada entre Sul e Norte, e que foi levada as últimas consequências com a Guerra de Secessão. ${ }^{68}$ No Brasil, a escravidão é abolida em 1888 e a República proclamada em 1889. Em Cuba, o fim da escravidão ocorre em 1886 e as lutas de independência perduram até 1898. A escravidão era a base de sustentação desses regimes políticos.

\section{Considerações Finais}

Nas sociedades do Antigo Regime cada corpus social possuía um determinado poder jurisdicional, cada uma dessas partes deveria preservar sua autonomia e se orientar de acordo com o bem comum. ${ }^{69}$ A definição do conceito de soberania, no final do século XVI, revelava a intencionalidade do poder real de afirmar seu poder sobre as partes que compunham a monarquia. $\mathrm{O}$ conceito de soberania destacava a idéia de dominium político e pretendia subordinar o dominium senhorial ao mesmo. No contexto do sistema colonial este conflito ficava evidente nas tentativas da Coroa de interferir no dominium dos senhores sobre seus escravos. Os colonos sempre resistiram a essa interferência. Porque esta rompia com o pacto político em que estava sustentado o sistema colonial: o reconhecimento do poder real dependia da legitimação do dominium sobre os nativos, fossem negros ou indígenas. Dito de outra maneira, o reconhecimento da soberania régia tinha como contrapartida o reconhecimento do dominium senhorial e do poder político local.

Mas a Coroa já sabia que o dominium pessoal, dos senhores sobre a mão-de-obra, significava autonomia e soberania política nas realidades coloniais. As leis que impediam a escravidão indígena, as tentativas de interferência no governo dos indígenas, o reconhecimento da liberdade dos mesmos, o estímulo e as tentativas de controle sobre a escravidão africana representaram um novo mecanismo para criar dependência dos colonos

67 “Diario de las Cortes del Congreso de los Diputados”. Sesión 29/1/1845, p. 1395. In: Ibidem, p. 400.

68 IZECKSOHN, Vitor. Op. cit., pp. 47-81.

69 HESPANHA. Op. cit., p. 21. 
em relação à metrópole. Era um novo pacto político-econômico que aumentava a soberania política da Coroa em relação aos colonos. Mas esse novo pacto logo revelou os mesmos limites, e o dominium dos senhores sobre os escravos africanos voltava a fundamentar o poder político local. O dominium senhorial se transformava em soberania política local: os colonos eram soberanos em sua própria terra. ${ }^{70}$

A historiografia que trata dos processos de independência parte das reformas de meados do século XVIII e as opõem a política Habsburgo, caracterizada como polisinódica. Essa distinção é falsa. Durante os séculos XVI e XVII os poderes jurisdicionais tinham muito mais força do que no século XVIII, mas isso não significa que a política Habsburgo tinha o sentido de preservação desses poderes. Uma análise da política ultramarina do período mostra o contrário e dá ao processo de formação do sistema colonial uma perspectiva de longa duração, onde os movimentos de reconhecimento do poder real e as exigências de preservação das jurisdições locais geram conflitos, acordos e negociações ao longo de toda a experiência colonial.

Marquese diferencia o discurso sobre o governo dos escravos elaborado no Brasil e em Cuba daquele elaborado nas Antilhas inglesas e francesas, nessas últimas não se desenvolveram os argumentos paternalistas. Os principais motivos desta diferenciação se encontram na superioridade numérica da população negra nas Antilhas e no absenteísmo dos grandes senhores de escravos. O fato é que a argumentação de tipo paternalista enfatiza o conceito de dominium patrimonial e equivale o governo dos escravos ao governo da família. Enquanto que os argumentos fundamentados no interesse e na humanidade enfatizam o conceito de dominium relacionado à propriedade privada e a liberdade individual dos brancos. No primeiro caso se admite e se legitima a manutenção da soberania na lógica do Antigo Regime. Enquanto que a segunda saída indica uma contradição em termos que deve evoluir para a ruptura com este sistema e com a própria escravidão.

As reformas coloniais de meados do século XVIII pretendiam impor a soberania real nas colônias: transformando a estrutura político-administrativa e interferindo tanto no negócio como no governo dos escravos. Isso já não era mais possível. O questionamento da soberania real ocorre simultaneamente na América e na Europa, sobre bases distintas. Criam um fluxo de idéias e projetos que circulam nos dois sentidos do Atlântico: a soberania podia estar em outro lugar, a liberdade também.

70 A referência é Sérgio Buarque de HOLANDA: "somos ainda hoje uns desterrados em nossa terra (...). Podemos construir obras excelentes, enriquecer nossa humanidade de aspectos novos e imprevistos (...) antes de perguntar até que ponto poderá alcançar êxito a tentativa, caberia averiguar até onde temos podido representar aquelas formas de convívio, instituições e idéias de que somos herdeiros." Raízes do Brasil. São Paulo, Companhia das Letras, 1995, p. 21. 


\section{Bibliografia}

1. ALBUQUERQUE, Luís de (dir.). Angola no Século XVI. Lisboa, Publicações Alfa, 1989.

2. ALENCASTRO, Luiz Felipe de. O Trato dos Viventes : formação do Brasil no Atlântico Sul. São Paulo, Companhia das Letras, 2000.

3. AMORES CARREDANO, Juan B. "La intendencia de La Habana en la etapa de las reformas borbónicas (1765-1790)". In: ZEUSKE, Michael (coord.). Las transformaciones hacia la sociedad moderna en América latina: causas y condiciones en la economía, la política y las mentalidades. Actas del X Congreso AHILA, 1993; Leipzig/Köln, 1996.

4. AMORES CARREDANO, Juan B. "La elite cubana y el reformismo borbónico". In LATASA (coord.), Pilar. Reformismo y sociedad en la América borbónica: In memoriam Ronald Escobedo. Barañain, EUNSA, 2003.

5. LATASA, Pilar. "El joven Arango y Parreño: origen del proyecto políticoeconómico de la sacarocracia habanera (1786-1794)". Temas Americanistas, 12, 1995, pp. 12-17.

6. ANDRÉS-GALLEGO, José. La esclavitud en la América española. Madri, Encuentro Ediciones S.A., 2005.

7. ANDRÉS-GALLEGO, José. Tres grandes cuestiones de la bistoria de Iberoamérica. Fundación Ignácio Larramendi, Fundación Mapfre Tavera. Madri, s.d. (CD-Rom).

8. ASHWORTH, John. Slavery, Capitalism, and Politics in the Antebellum Republic. Nova York e Cambridge, Cambridge University Press, 1995, vol. 1.

9. BERLIN, Ira. Many thousands gone - the first two centuries of slavery in North America. Cambridge, Mass., Belknap Press, 1998.

10. Biblioteca Virtual Miguel de Cervantes. Miscelánea de textos breves relativos a la época del emperador. Espanha, Madri. Disponível em:

http://www.cervantesvirtual.com/historia/CarlosV/9_15.shtml. 9 de enero de 2007.

11. BLACBURN, Robin. The making of New World slavery - from the Baroque to the Modern, 1492-1800. Londres, Verso, 1997.

12. BODIN, Jean. Les six livres de la République. Paris, 1576, ou, Darmstadt, Scientia Verlag Aalen, 1977 (fac-simile de la deuxième édition, Paris, 1583).

13. BONCIANI, Rodrigo Faustinoni. "A política ultramarina de Felipe III no Brasil e em Angola: o governo do gentio e o comércio de escravos (1607-1621)". In Actas do IIIColóquio Internacional : Trabalho Forçado Africano. Porto, Universidade do Porto, 2007.

14. BOSI, Alfredo. Dialética da colonização. São Paulo, Companhia das Letras, 1994.

15. BRÁSIO, Padre António (org.). Monumenta Missionaria Africana. Lisboa, Agência Geral do Ultramar, $1^{a}$ série, 1953-88, vols. III, IV, XV.

16. DEBBASH, Yvan. "Au coeur du 'gouvernement des esclaves', la souveraineté domestique aux Antilles françaises (XVIe-XVIIIe siècles)". Revue Française d'Histoire d'Outre-Mer. LXXII, nº 266, 1985, pp. 31-54.

17. DOMÍNGUEZ, Jorge I. Insurrección o lealtad. La desintegración del Imperio español en América. México, Fondo de Cultura Económica, 1985.

18. EDWARDS, Bryan. History, civil and commercial, of the British colonies in the West Indies. Londres, John Stockdale, 1794.

19. FAORO, Raymundo. Os Donos do Poder: formação do patronato político brasileiro. São Paulo, Globo-Publifolha, 2000, 2 vols.

20. FICK, Carolyn. The making of Haiti - The Saint Domingue Revolution from Below. Knoxville, The University of Tennessee Press, 1990.

21. FISCHER, John (ed.). Actas del XI Congreso Internacional de AHILA. Liverpool, 1998, vol. II. 
22. FISCHER, Sibylle M. Modernity disavowed: Haiti and the cultures of slavery in the age of revolution. Durham, Londres, Duke University Press, 2004.

23. FOGEL, R. e ENGERMAN, S. Time on the Cross: The Economics of American Negro Slavery. Boston, Little Brown and Company, 1974.

24. HESPANHA, António M. "Para uma teoria da história institucional do Antigo Regime". In Poder e instituições na Europa do Antigo Regime. Lisboa, Fundação Calouste Gulbenkian, 1984.

25. HOLANDA, Sérgio Buarque de. Raízes do Brasil. São Paulo, Companhia das Letras, 1995.

26. IZECKSOHN, Vitor. "Escravidão, Federalismo e Democracia: a luta pelo controle do Estado nacional norte-americano antes da Secessão". Topoi, Rio de Janeiro, n.6, 2003, pp. 47-81.

27. JAMES, C.L.R. Los jacobinos negros : Toussaint L'Ouverture y la Revolucion de Haiti. Madri, Turner; México, Fondo de Cultura Económica, 2003. JANCSÓ, István e PIMENTA, João Paulo G. "Peças de um mosaico (ou apontamentos para o estudo da emergência da identidade nacional brasileira)". Texto inédito. São Paulo, Universidade de São Paulo, 2000.

28. JORDAN, Winthrop. White over black - American attitudes toward the negro, 1550-1812. Chapel Hill, University of North Carolina Press, 1968.

29. KUETHE, Allan J. Cuba 1753-1815, Crown, Military and Society. Knoxville, The University of Tennessee Press, 1986.

30. LARA, Silvia Hunold (org.). "Legislação sobre escravos africanos na América portuguesa”. In: ANDRÉS-GALLEGO, José (dir. e coord.). Tres grandes cuestiones de la historia de Iberoamérica. Fundación Ignácio Larramendi, Fundación Mapfre Tavera. Madri, s.d. (CD-Rom).

31. LEÓN y PIZARRO, José García de. "Memorias de José García de León Pizarro (1770-1835)". Revista de Occidente, Madri, 1953, 2 vols.

32. LÓPEZ MEDEL, Tomás. Colonización de América : informes y testimonios (1549-1572). Madri, Consejo Superior de Investigaciones Científicas, 1990.

33. LUCENA SALMORAL, Manuel. "Leyes para esclavos : El ordenamiento jurídico sobre la condición, tratamiento, defensa y represión de los esclavos en las colonias de la América español”. In: ANDRÉS-GALLEGO, José (dir. e coord.). Tres grandes cuestiones de la bistoria de Iberoamérica. Fundación Ignácio Larramendi, Fundación Mapfre Tavera. Madri, s.d. (CD-Rom).

34. MARQUESE, Rafael de Bivar. Feitores do corpo, missionários da mente : Senhores, letrados e o controle dos escravos nas Américas, 1660-1860. São Paulo, Companhia das Letras, 2004.

35. MAURO, Fréderic. Portugal, o Brasil e o Atlântico. Lisboa, Editorial Estampa, 1989, 2 vols.

36. MORGAN, Edmund. American slavery, American freedom. The ordeal of colonial Virginia. Nova York, W. W. Norton, 1975.

37. MORGAN, Philip. Slave counterpoint - black culture in the eighteenth century Chesapeake \& lowcountry. Chapel Hill, University of North Carolina Press, 1998.

38. NOVAIS, Fernando A. Estrutura e dinâmica do antigo sistema colonial. São Paulo, Brasiliense, 1998.

39. NOVAIS, Fernando A. Portugal e o Brasil na Crise do Antigo Sistema Colonial (17771808). São Paulo, Hucitec, 1981.

40. SALA-MOLINS, Louis. Le Code noir, on le calvaire de Canaan. Paris, PUF, 1987. SANTOS, Catarina Madeira. "A formação das estruturas fundiárias e a territorialização das tensões sociais: São Tomé, primeira metade do século XVI". Revista STVDLA, n ${ }^{\circ}$ 54/55, 1996, pp. 51-91. 
41. SCELLE, Georges. La traite négrière aux Indes de Castille. Paris, Librairie de la Societé du Recueil, J. -B. Sirey \& du Journal du Palais, 1906, 2 vols.

42. SCHULTZ, Kirsten. "La independencia de Brasil, la ciudadanía y el problema de la esclavitud: A Assembléia Constituinte de 1823". In: RODRÍGUEZ O., Jaime (coord.). Revolución, independencia y las nuevas naciones de América. Madri, Fundación Mapfre Tavera, 2005, pp. 425-449.

43. SCHUWARTZ, Roberto. Ao Vencedor as Batatas. Livraria Duas Cidades, São Paulo, 1977.

44. SCHWARTZ, Stuart B. Burocracia e sociedade no Brasil colonial. São Paulo, Perspectiva, 1979.

45. SMITH, Adam. A riqueza das nações - investigações sobre sua natureza e suas causas. São Paulo, Nova Cultural, 1996.

46. THOMAS, Georg. Politica indigenista dos portugueses no Brasil. São Paulo, Loyola, 1982.

47. VILA VILAR, Enriqueta. "La esclavitud americana en la política española del siglo XIX”. Estudios Latinoamericanos, 6, II, 1980, pp. 385-403.

48. WEBER, David J. Bárbaros : Los españoles y sus salvajes en la era de la Ilustración. Barcelona, Crítica, 2007.

49. ZERON, Carlos A. de Moura R. Tese de doutorado: La Compagnie de Jésus et l'institution de l'esclavage au Brésil : les justifications d'ordre historique, théologique et juridique, et leur intégration par une mémoire historique (XVI-XVII siècles). Ecole des Hautes Etudes en Sciences Sociales de Paris, 1998.

50. ZEUSKE, M (coord.). Las transformaciones hacia la sociedad moderna en América latina: causas y condiciones en la economía, la política y las mentalidades. Actas del X Congreso AHILA, 1993, Leipzig/Köln, 1996. 